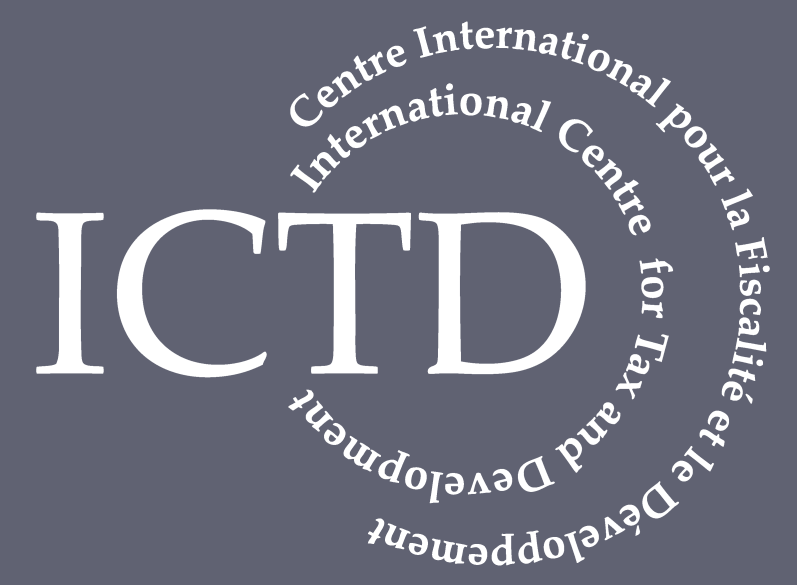

Working Paper 70

\title{
How Can Governments of Low-Income Countries Collect More Tax Revenue?
}

Mick Moore and Wilson Prichard

November 2017

BILL \& MELINDA

GATES foundation
NQR

UKaid 
ICTD Working Paper 70

\section{How Can Governments of Low-Income Countries Collect More Tax Revenue?}

Mick Moore and Wilson Prichard

November 2017 
How Can Governments of Low-Income Countries Collect More Tax Revenue?

Mick Moore and Wilson Prichard

ICTD Working Paper 70

First published by the Institute of Development Studies in November 2017

(C) Institute of Development Studies 2017

ISBN: 978-1-78118-403-5

\section{(c) (1) ()}

This is an Open Access paper distributed under the terms of the Creative Commons Attribution Non Commercial 4.0 International license, which permits downloading and sharing provided the original authors and source are credited - but the work is not used for commercial purposes. http://creativecommons.org/licenses/by-nc/4.0/legalcode

Available from:

The International Centre for Tax and Development at the Institute of Development Studies, Brighton BN1 9RE, UK

Tel: +44 (0) 1273606261

Email: info@ictd.ac.uk

Web: www.ictd/en/publications

IDS is a charitable company limited by guarantee and registered in England

Charity Registration Number 306371

Charitable Company Number 877338 


\title{
How Can Governments of Low-Income Countries Collect More Tax Revenue?
}

\author{
Mick Moore and Wilson Prichard
}

\section{Summary}

It is widely believed that the governments of many low-income countries, and especially the relatively poor performers, should be aiming to increase the proportion of GDP they raise in tax revenue. There are risks in emphasising increasing revenue at the expense of other objectives. Governments also need to be concerned with questions of equity, efficiency, trust and reciprocity, among others. However, the question of how governments can further increase revenue is a central part of that broader story. It is a big question. We address it by answering three more precise questions.

1. Which specific potential revenue sources do governments generally tend to underexploit? This leads to a list of eight ways of potentially increasing revenue: more actively and effectively combating the transfer mispricing activities of transnational firms; taxing mining activities better; increasing excise taxes on tobacco and alcohol; reducing tax exemptions for investors; implementing valued added tax (VAT) more effectively; more actively taxing the income and assets of the fast-expanding numbers of rich citizens; taxing more heavily the ownership and occupation of urban real estate; and obliging government agencies to be better 'tax citizens'.

2. What are the possibilities of increasing revenue through generally improving tax administration? There seems to be considerable potential, notably to use information and communications technology (ICT) facilities more effectively to manage core business processes, including accounting for tax revenue receipts in more integrated, centralised and transparent ways.

3. What is the scope for increasing revenue through changes to both domestic and international tax policies? Some of the more promising possibilities are: complementing corporate profit taxes with taxes on turnover; signing fewer bilateral international tax treaties; more regional inter-governmental cooperation around a range of tax policy issues; and improving the tools for taxing wealthy individuals.

Tax is very political, but so are many things that governments need to do. There is no reason to believe that political obstacles to reform are unusually high in the tax area.

Keywords: government revenue; low-income countries; transfer mispricing; mining tax; tax exemptions; property taxes; tax treaties.

Mick Moore is a Professorial Fellow at the Institute of Development Studies, and the founding Chief Executive Officer of the International Centre for Tax and Development (ICTD).

Wilson Prichard is an Associate Professor jointly appointed to the Department of Political Science and the Munk School of Global Affairs at the University of Toronto. He is also a Research Fellow at the Institute of Development Studies at the University of Sussex, and a Research Director of the International Centre for Tax and Development. 


\section{Contents}

Summary 3

Acknowledgements

Acronyms $\quad 5$

Introduction 6

$1 \quad$ Dangling fruit $\quad 8$

1.1 Transfer mispricing in international economic transactions 8

$\begin{array}{lll}1.2 & \text { Mining } & 11\end{array}$

1.3 Tobacco and alcohol 13

$\begin{array}{lll}1.4 & \text { Exemptions } & 13\end{array}$

$\begin{array}{lll}1.5 & \text { Implementing VAT } & 14\end{array}$

$\begin{array}{lll}1.6 & \text { Taxing the rich } & 15\end{array}$

1.7 Property taxes 16

1.8 Turning government organisations into better tax citizens 17

$2 \quad$ Improving organisational performance 18

$3 \quad$ Changing tax policies $\quad 20$

3.1 Tax companies more on turnover, and less on reported profits 20

$\begin{array}{lll}3.2 & \text { Beware of tax treaties } & 21\end{array}$

3.3 Act regionally on tax exemptions and international tax rules 22

3.4 Improve the tools for taxing the wealthy 23

4 Politics $\quad 23$

5 Conclusion $\quad 25$

$\begin{array}{ll}\text { References } & 26\end{array}$ 


\section{Acknowledgements}

This paper is based on what we have learned from a wide range of practitioners and researchers. We owe special thanks to our colleagues at the ICTD and those working on ICTD research projects, notably: Michael Durst, Odd-Helge Fjeldstad, Tom Goodfellow, Samuel Jibao, Jalia Kangave, Olav Lundstol, Giulia Mascagni, Rhiannon McCluskey, Milly Nalukwago, Sol Picciotto, Henry Saka, Vanessa van den Boogaard, Ronald Waiswa and Nyah Zebong. For very useful comments on an earlier draft, we are especially grateful to Jan Isaksen, Olav Lundstol and Justin Zake.

\section{Acronyms}

$\begin{array}{ll}\text { ATAF } & \text { African Tax Administration Forum } \\ \text { BEPS } & \text { Base erosion and profit shifting } \\ \text { TIN } & \text { Taxpayer Identification Number } \\ \text { VAT } & \text { Value added tax }\end{array}$




\section{Introduction}

There is currently something of an international consensus that the governments of lowincome countries should be aiming to tax more - to increase the proportion of GDP that they collect in taxes. This consensus is embodied in the immediate outcomes of the 2015 Third International Conference on Financing for Development - the Addis Ababa Action Agenda and the Addis Tax Initiative - and in a range of subsequent statements and programmes. A proposal that governments would normally be expected to raise revenue equivalent to at least 20 per cent of GDP was formally defeated at the Addis Ababa meeting. But the notion that there should be some target for the minimum acceptable level of national revenue collection has not gone away. The figure of 15 per cent of GDP is now widely cited. Whatever one's views on such targets in general, or on this precise figure,$^{1}$ there is now a widespread feeling that governments that appear as laggards in the revenue collection business should raise their game. ${ }^{2} \mathrm{~A}$ range of reasons are given. The most tangible is the need to finance the public spending programmes required for achievement of the Sustainable Development Goals by 2030. At a more theoretical level, there are claims that increases in tax collection might generate beneficial by-products in the form of improvements in the quality of governance, while also addressing economic inequality. There is also a vision of traditional aid donors bowing out gracefully and constructively from the era of 'big aid' by supporting a push to raise substitute domestic revenue sources in formerly aiddependent countries. The most recent statistics indicate that low-income countries are already moving in this direction. Since 2010, the average ratio of tax collection to GDP has increased quite markedly in low-income countries, while changing little in other parts of the world. ${ }^{3}$

We have reservations about an uncritical consensus in favour of higher revenue collection. Above all, the public benefits of expanded taxation are unlikely to be realised without a corresponding focus on (a) improving the equity of tax collection, which is frequently characterised by corruption, extractions that fail to reach state budgets, and a failure to consistently and adequately tax the wealthy and politically connected, and (b) ensuring that taxpayers get better value for their money through improved public spending. The push to expand revenue collection is sometimes motivated by the idea that paying taxes is not a routine practice for citizens of low-income countries. The reality, however, is that while some taxpayers may escape paying their fair share, others pay more than their share. In particular, in some countries poorer citizens sometimes bear especially heavy burdens of both formal and informal taxes (Jibao et al. 2017; Paler et al. 2017). Without an equivalent focus on how tax is collected, from whom, and how the revenue is spent, a simple emphasis on increasing collection risks exacerbating existing inequities.

Nevertheless, and with the provisos set out above, there are good reasons for the governments of many low-income countries to take advantage of the current international consensus to find ways of raising additional revenue. Ethiopia is a good example. The

\footnotetext{
This sounds precise, but in practice is open to interpretation. The number of countries currently falling below this $15 \%$ threshold would depend very much on the exact measure of the concept of tax-to-GDP ratio to be used. If it were decided to take into account: (a) all government rather than simply central government revenue, (b) total revenue (i.e. including non-tax revenue) rather than simply tax revenue, and (c) social security contributions collected by government, then only a handful of countries would currently fall below the $15 \%$ threshold. Conversely, if the three quantities listed above were excluded from the calculation, the number of countries that would qualify as under-taxed would increase considerably. (See ICTD Government Revenue Dataset <http://www.ictd.ac/datasets/the-ictd-government-revenuedataset>.) Further, GDP figures are often quite unreliable (Jerven 2013).

2 Generally speaking, governments that collect an unusually low proportion of GDP in revenue tend to be concentrated in South Asia and Central America. There are few in Africa. For statistics, see $<$ https://www.wider.unu.edu/project/government-revenue-dataset>.

So that the conclusions will be unaffected by changes in global market prices for oil, gas and minerals, we have used figures for non-resource revenue, i.e. they exclude governments' royalty and tax income from the extractives sector. The detailed figures are available at <https://www.wider.unu.edu/project/government-revenue-dataset> .
} 
government would likely use any additional revenue for good public purposes - the needs are crystal clear. But it is intrinsically difficult to raise revenue from this very low-income, dominantly rural economy with limited international trade. ${ }^{4}$ How then should policymakers in Ethiopia and elsewhere set about increasing what we will henceforth term the 'tax take' - the proportion of GDP collected as government (tax and non-tax ${ }^{5}$ ) revenue? The main constraints on increasing tax revenue are rarely narrow and technical. They are a complex mixture of what is politically and organisationally feasible, where feasibility is likely to be subjective and political, and to depend on the political and organisational skills of those trying to lead the change. Political judgements and political commitments are in most cases best made domestically. External agencies can be most useful by providing financial and technical support and, sometimes, by taking the blame for the hurt that reform might inflict on some taxpayers. It can be very convenient for governments to claim: 'We had no choice. The IMF forced us to do it'.

How can we begin to answer the question: how can governments of low-income countries collect more tax revenue? This is potentially quite a brain-teaser. There is no 'scientific' (i.e. consistent, logically coherent, numbers-based) answer. One might in principle look at every country individually, and begin with a 'tax gap' analysis - an estimate of the differences between the taxes actually collected and those that should be collected in the light of the national tax code and the structure of the economy. Practically, this is very demanding. Conceptually, it falls into a problem of circularity: whether there is potential additional revenue from any particular source depends in part on tax policy. For example, if a government has made no legal provision for taxing capital gains, then a tax gap analysis will simply not take into account the revenue that could in principle be obtained by taxing capital gains. ${ }^{6}$ Likewise, the tax domains with the largest tax gap may not necessarily be the best place to look for increased revenue. Some revenue sources may be more politically or technically feasible. Others may be attractive because, in addition to offering additional revenue, they bring benefits like greater equity, support for economic growth, stimulus to improved governance and more fiscal decentralisation. ${ }^{7}$

Our procedure here is more intuitive and subjective. We have deconstructed the big question of how governments can increase the tax take into three smaller questions. The answers to those questions overlap, but imperfectly. We deal with them sequentially:

- What specific potential revenue sources do the governments of many developing countries tend to under-exploit? We term this the 'dangling fruit' issue (Section 1).

- What is the potential for increasing the tax take through improving tax administration generally - and what specific kinds of strategies might be particularly useful? This is the 'organisational performance' issue (Section 2).

- What is the potential for increasing the tax take through changing domestic and international tax policies? This is the 'tax policy' issue (Section 3).

Because in most low-income countries central government agencies collect nearly all revenue harvested by the state, we focus on central government. We only deal tangentially with the important question of enhancing sub-national revenue - in the discussion of property taxes in Section 1. Neither do we debate what seems in many contexts to be the most obvious and direct way to increase tax take: to increase the rates of existing taxes -

\footnotetext{
In any economy with these features, revenue collection as a proportion of GDP is likely to be low (Bird et al. 2008; Fauvelle-Aymar 1999; Gupta 2007; Minh Le et al. 2012; Pessino and Fenochietto 2010; Piancastelli 2001).

Broadly, non-tax revenue refers to the income that governments earn from directly providing services and/or owning assets. This would include, for example, the profits from operating or leasing out ports, airports, water and electricity supply; revenue from sales of natural resources (land, minerals); and charges for issuing passports. In practice, the distinction between tax and non-tax revenue is unclear and variable. It is not relevant to the subject of this paper. For a discussion of more technical problems with tax gap analysis, see Gemmell and Hasseldine (2014).

Among the other analytic tools available, measures of tax effort may be of some use in addressing our question, while the concept of optimal taxation is practically irrelevant to the circumstances of low-income countries.
} 
including income, profit and withholding taxes, VAT and customs duties. Our ideas may be least relevant to fragile states, which, even more than other countries, are likely to require policies highly tailored to their specific circumstances.

By presuming to indicate how governments of low-income countries might raise additional revenue, we risk being accused of promoting one-size-fits-all policies. We are certainly not suggesting a fixed menu. Part of our offering are ways of thinking strategically about the task of increasing the tax take. The other part is more concrete: suggesting some specific, potentially large revenue sources that we believe are, on average, under-exploited in lowincome countries, along with some potential strategies for tapping them more effectively. Our menu is not fixed, but does contain some recommended items.

\section{Dangling fruit}

Dangling fruit are not necessarily low-hanging fruit: gains that can be harvested with little effort. The term refers rather to those specific potential sources of large additional tax revenue that seem generally to be under-exploited in many low-income countries. They are ripe for attention. Exploiting them successfully may require a great deal of political and organisational effort. That may not necessarily pay off in the short term. In the longer term, these dangling fruits are too tempting and potentially too large to ignore. We have identified eight. We are unable to rank them in terms of potential revenue. This will vary according to context. To give a sense of the magnitudes involved, we guesstimate that, over a period of five to ten years, each has the potential to increase the tax take by 1-2 per cent of GDP, and perhaps significantly more. If history is a guide, no country should reasonably be expected to make such rapid progress on multiple fronts all at once. The key point, nonetheless, is that each of these dangling fruits has the potential to make a significant difference to national revenue collection.

For convenience of exposition, we discuss first those dangling fruit where the international dimension is most evident.

\subsection{Transfer mispricing in international economic transactions ${ }^{8}$}

A high proportion of international trade is between what lawyers call 'related parties' - agents that are not independent of one another, but connected through ownership or influence. The most important related parties for present purposes are companies that comprise part of the same transnational corporate group. The prices at which related parties trade goods and services between themselves across international borders are unlikely to be set through competitive market bidding. They are set partly or wholly through administrative decisions about what price levels would most benefit the larger corporation to which the related parties belong. Indeed, since the typical transnational corporation exists precisely to manage a set of operations that are integrated internationally or globally, it may be very difficult even for its best accountants to accurately calculate a market-like price for transactions between two of its subsidiary companies.

8 One of the best summaries of the issues discussed here is IMF (2014). 


\begin{abstract}
Box 1
Imagine a transnational corporation called HydroEng that manufactures state-of-the art electronically-controlled pumping equipment in Germany. It also invests heavily in research and development operations in the Netherlands. A subsidiary incorporated in Nigeria, HydroEngNigeria, has a thirty-year contract to build, manage and maintain a large drainage and water management facility in Lagos. HydroEngNigeria regularly despatches motors, pumps and other complex items of equipment to a specialised facility in South Africa, owned by HydroEngDurban, where they are serviced and repaired, often by specialist engineers who fly in from Germany. Even HydroEng's own accountants are challenged to estimate the real cost to the company of providing this maintenance and repair service. In addition to many other variables, they have to factor in the high research and development expenditure that underlies the corporation's competitiveness. This situation is so much more challenging for the Nigerian tax authorities, who have no access to HydroEng's internal management accounts, to verify the validity of the price that HydroEngDurban charges HydroEngNigeria for this service. According to the standard procedures of the international tax system, they should seek a few comparators - other cases of companies providing similar maintenance services for electronically-controlled pumping equipment in Nigeria - where prices are not administratively controlled, but set in competitive markets. Some average of the prices of comparators would provide a benchmark for the appropriate price for this transaction. In reality, appropriate comparators are often scarce or absent.
\end{abstract}

The hypothetical example in Box 1 illustrates the essence of the transfer pricing and mispricing problem. Given the basic structure of HydroEng - with locally-incorporated subsidiary companies, taxable locally, responsible for local operations in Nigeria, South Africa and perhaps dozens of other countries - someone has to set a transfer price so that the accounts of HydroEngNigeria and HydroEngDurban can be closed at the end of the year and tax returns submitted. Transfer pricing is inevitable. If the companies involved deliberately set that price in order to shift profits among jurisdictions, then we say that they are practising transfer mispricing. We know that: (a) transfer mispricing is widespread; (b) it is used mainly to transfer profits from higher-tax to lower-tax jurisdictions; and (c) these transfers are especially likely to be from low-income countries to high-income countries and tax havens. ${ }^{9}$

The policy issue for developing countries is: how much effort to invest in auditing challenging and interrogating - the tax accounts presented by transnational corporations for potential transfer mispricing $?^{10}$ On this point there is significant disagreement. Part of it centres on how much revenue is available to be collected by improved enforcement. Widespread international attention to these issues has been driven in part by very large estimates of illicit financial flows, with the implication that these imply very large tax losses. ${ }^{11}$ However, it is increasingly clear that the larger estimates of the size of these illicit flows are substantially inflated (Forstater 2017b), as are guesses about the amount of revenue loss this implies for governments of low-income countries (Forstater 2017a). More credible, but still very rough, estimates seem to point towards revenue losses on the scale of perhaps 2 per cent of GDP on average in low-income countries, though with big variations across countries - and likely much higher figures for natural resource-exporting countries. Stemming these losses would generate significant revenue. It would not provide the deep pot of gold that some campaigners have promised. The most recent and careful estimates, by

\footnotetext{
$9 \quad$ There are a range of reasons for this pattern of flows, including: the biases in existing laws and international tax treaties and agreements; the lesser capacity of government institutions in low-income countries to control abuses; and a reluctance on the part of companies and wealthy individuals to hold large amounts of capital in politically fragile countries.

10 Transfer mispricing is not restricted to related parties. Two independent firms may also collude to shift profits among jurisdictions. It is generally assumed that this is a minor problem compared to transfer mispricing between related parties.

11 'Illicit financial flows' is not a technical term in economics or accounting. There is no agreed definition (Johannesen and Pirttilä 2016). Broadly, the concept represents the sum of (a) the profits that transnational and other companies move abroad through the use of transfer mispricing and other profit-shifting techniques, and (b) the capital that wealthy, influential people transfer abroad using illegal or illicit channels. The 'taxes foregone' are the taxes that might have been collected on these profit and capital transfers in the country from which they are made.
} 
Johannesen and Pirttilä (2016), imply that the revenue losses to African governments from illicit financial flows are lower than aggregate official development assistance - and not the multiple that is sometimes claimed. The second source of disagreement relates to the capacity of government institutions in developing countries to actually tap this potential additional revenue. Transnational companies typically employ large numbers of skilled lawyers and accountants to help minimise their tax bills. Tax administrations in many lowincome countries are, by comparison, very poorly resourced: they face major challenges. Finally, there are questions about whether, by inducing increases in corporate tax collection, better enforcement of transfer pricing rules could have negative effects on investment levels. Evidence is limited, but it is inadvisable for governments of low-income countries to be overly concerned about this possibility. Research suggests that in low-income countries tax levels are less of a constraint on investment than a range of other investment climate concerns, including the quality of public infrastructure (roads, ports, electricity, water and broadband) and public institutions (the legal system), and the predictability of the tax system (Kinda 2014). However, a poorly executed programme of auditing for potential transfer mispricing could discourage investment by increasing the perceived unpredictability of the tax system.

On balance, there are good reasons to believe that for most low-income countries - indeed, for most countries in the world - challenging corporate accounts for potential transfer mispricing is either a sensible strategy for today or an appropriate aim for tomorrow, once capacity is developed:

- The evidence suggests that, when tax administrations mount serious challenges to transfer mispricing, they tend to be rewarded by substantial additional revenue. This is true even in countries that have historically not been tolerant of transfer mispricing. As in many rich countries, the British tax authority has in recent years invested additional resources in challenging transnational corporations, especially through strengthening its transfer pricing team. The authority sees this as a major reason why corporate income tax revenue increased by 12 per cent in 2016/17 compared to the previous year. ${ }^{12}$ There is convincing evidence that the cost-benefit ratio of aid to support transfer pricing audits in low-income countries is extremely high. In a private communication, Olav Lundstol of the Norwegian Agency for Development Cooperation reports that the first year returns to recent such investments in Zambia and Tanzania have been around 10:1 and 100:1 respectively. OECD assistance has generated similar results. ${ }^{13}$

- There is a clear global trend for governments and tax administrations to devote more resources to challenging transfer mispricing. Until the late 1980s, very few tax administrations in the world - and virtually none in low-income countries - had transfer pricing laws and regulations. This is changing. ${ }^{14}$ In 2000 , only two countries in Africa South Africa and Zambia - had these laws and regulations in place. This number increased to seven by 2005, and fourteen by the end of 2014 (EY 2014: 14). An increasing amount of training on how to deal with transfer mispricing is available internationally. The quality of staff in tax administrations in low-income countries is rising. Most tangibly, there has been great progress in the last two years in establishing global

12 The British tax authority also reports that, following a transfer pricing challenge, the additional tax collected is typically around a half of the figure that the authority initially suggests (Financial Times 30 August 2017).

Over a two-year period, 2015-17, a joint programme between the OECD and the African Tax Administration Forum (ATAF) to provide technical assistance support to transfer pricing audits in Africa has generated additional revenue of more than US\$120 million. For one West African country, in a single year, these audits led to a twelve-fold increase in the revenue earned from challenging for transfer mispricing. This information was provided by Lee Corrick, an OECD/ATAF transfer pricing expert, in a personal communication on 12 September 2017.

14 This trend was motivated largely by the rapid growth in both the number and complexity of cross-border economic transactions since the 1960s, and increasing awareness of the scope for transfer mispricing. While the expansion of transnational manufacturing production chains increases the scope for transfer mispricing, large-scale transfer mispricing now derives more from related party transactions in finance and intangibles, notably intellectual property rights, than from trade in material goods. 
institutions through which tax administrations can (more or less easily) exchange information about 'taxpayers of interest' with one another. ${ }^{15}$

The potential additional revenue from more effectively tackling transfer mispricing seems significant. ${ }^{16}$ It would be curious - and indeed suspicious - if tax administrations in lowincome countries were not steadily to make more use of the tools that are becoming available to them. Not to do so would be equivalent to a police force refraining from shifting to the widespread use of digital technologies on the grounds that most of its staff were not digitally literate, there was no budget for new hardware and software, and that anyway criminals would always outdo them in digital resources and expertise, so it would not be worth entering the race.

That said, we need to recognise that not all tax administrations in low-income countries are in a position to significantly increase revenue through transfer pricing audits within the next few years. Some countries as yet have no transfer pricing legislation or regulations. In others, like Nigeria, there are contradictions between the legislation and regulations. Other countries have legislation and regulations in place, but in practice do not use them. There are a range of reasons for this. Effectively challenging for transfer mispricing can be difficult. It requires considerable resources, including knowledge, staff and capacity to access information from commercial databases or from tax agencies overseas. It is often a long-term game, with individual investigations taking months or years, while tax administrations are focused on meeting annual revenue collection targets. The legislation is not always watertight. Transfer pricing cases are typically so complex that it is too costly to take them to court. The Kenya Revenue Authority is one of the most effective tax administrations in sub-Saharan Africa, and an acknowledged leader in transfer pricing issues. However, recent research shows that it still has a way to go to be effective (Waris 2017).

The OECD approach to transfer pricing is virtually the global standard. It was originally designed for the institutional and economic conditions of rich OECD countries: relatively deep and competitive import and export markets, extensive recording of economic transactions, and well-equipped tax authorities. Many tax administrations in low-income countries find themselves unable to deploy it effectively. They are seeking simpler, more effective tools to curb transfer mispricing. There is work to be done to support them. ${ }^{17}$

\subsection{Mining ${ }^{18}$}

The economic importance of mining varies significantly from one country to another, and changes over time as global prices for minerals fluctuate. Recent decades have seen the (re)emergence of mining in particular - and resource extraction in general (i.e. oil, gas and minerals) - as a major activity, especially in sub-Saharan Africa. This seems set to continue. Extractives are a dominant source of export revenue. While some minerals, like coal, may face a long-term price decline, others, including rare earths, have buoyant market prospects.

\footnotetext{
15 We refer to the Global Forum on Transparency and Exchange of Information for Tax Purposes $<$ http://www.oecd.org/tax/transparency/automaticexchangeofinformation.htm>.

For a brief summary of some recent research, see Forstater (2017a). A recent estimate from the IMF, which includes other sources of revenue loss through base erosion and profit shifting, in addition to transfer mispricing, mentions a figure possibly as high as $1 \%$ of GDP for developing countries generally (IMF 2014). That represents approximately $5 \%$ of current revenue collection for the typical developing country.

17 Transfer pricing methods and issues become very complex. The OECD approach is based on the arm's length principle (ALP): estimating what transfer prices should be used by using data from other comparable (market, non-administered) transactions. If this approach proves unworkable, the OECD and/or other authorities allow or practice a range of alternatives. They include: different methods of estimating what transfer prices should be used; starting from norms about the rate of profit that companies could expect to earn; and using short cuts like safe harbours to agree a range of permissible transfer prices.

There is a large literature on this topic. See, in particular, Aarsnes and Lundstol (2013); Africa Progress Panel (2013); Collier (2010); Daniel et al. (2010); Daniel et al. (2016); Durst (2016); Laporte and de Quatrebarbes (2015); Lundstøl et al. (2013); Moore and Lundstol (2016).
} 
In low-income countries mining is generally very much under-taxed - and much more so than the other main components of the extractive sector, oil and gas. The reasons are both technically complex and deeply political. ${ }^{19}$ Almost all mine operators are large transnational companies. Few other organisations can generate the very high levels of capital that mining requires, and bear the high risks involved. The rents - the unearned profits - extracted from mining can be vast. Debates around the taxation of mining are fundamentally about how these rents will be distributed between transnational investors, government treasuries, and, via corruption of many kinds, the political elites who enjoy effective control over access to the right to mine mineral resources. Significant chunks of the revenue from mining that should be paid into public treasuries are often siphoned off, through a combination of collusion between mining companies and various political operators, and more straightforward forms of tax evasion. The main specific channels through which revenue is lost are:

- Mining contracts: these are often overly generous to investors, and in effect private deals between them and a few people who control the host government. Open and honest auctions of mining rights are a widely advocated potential antidote - but rarely practised.

- Transfer pricing: because almost all mining is conducted by locally-incorporated subsidiaries of large transnational companies, and almost all mining products from lowincome countries are exported, the scope to use transfer mispricing to shift profits out of the host country is very wide. The operating companies typically purchase most of their equipment and expertise from related parties, and sell all their product to other related parties. ${ }^{20}$

- The tax regime: a high degree of reliance on corporate income taxes as the instrument for obtaining revenue from mining is very risky from the government perspective, because transfer mispricing can be used to grossly understate the profits of the local mine operator. One feasible alternative is for governments to focus more on obtaining revenue through royalties - the charges that mining companies pay for the national assets (copper, coal, titanium, gold, etc.) that they are removing and selling. ${ }^{21}$

- Capital gains: mining projects frequently undergo one or more changes of ownership at a relatively early stage. A 'junior' company with a low public profile and limited concern for its corporate reputation organises the exploration and securing of land and extraction rights. The operation is then sold to one of the larger transnational mining companies that are more concerned about reputational issues. The sale typically takes place offshore, between companies domiciled in tax havens. ${ }^{22}$ The question of whether the company making the sale should be liable for capital gains tax in the host country has been the subject of high profile law cases, because much national legislation is ambiguous or silent on the issue. To date, companies have more frequently been the winners. ${ }^{23}$ This particular piece of dangling fruit may be low hanging for many countries.

One of the likely reasons why oil and gas are less under-taxed than mining is that, because oil and gas projects are generally technically and technologically more demanding, especially when conducted offshore, they are typically organised as joint ventures between two or more private or state-owned companies. Because the partners in these joint ventures need to share information on operations and revenue, it is less easy for operating companies to engage in transfer mispricing by presenting misleading information to tax authorities.

20 They may also manipulate information on the quantity and quality of mineral exports in order to reduced reported revenue (Readhead 2016, 2017; Durst 2016).

21 Because market prices for minerals fluctuate widely, an excessive reliance on royalties risks pushing mining companies into operating losses when commodity prices are low. This, in turn, could lead them to reduce their scale of operations excessively, to the detriment of the host economy. The risk can, however, be ameliorated through the use of variable rate royalties, i.e. royalties that are pegged to world market prices for the product (Durst 2016).

22 For example, UraniumCo, a company incorporated in Niger that has established rights to extract radioactive chemicals, might be sold by the Canadian company that owns it to an Australian mining conglomerate. But the transaction will be between a subsidiary of the Canadian company incorporated in the British Virgin Islands and a subsidiary of the Australian company incorporated in Luxembourg.

23 In 2015 Tullow Oil, having lost a case in the Uganda High Court, finally accepted that it owed the Uganda Revenue Authority $\$ 250$ million in relation to an offshore sale of this nature. However, this is not the norm. 


\subsection{Tobacco and alcohol ${ }^{24}$}

Governments of most richer countries collect useful amounts of revenue from excise taxes levied on specific commodities, especially on tobacco and alcohol. We do not have reliable detailed and accessible figures on revenue raised in developing countries. They are, however, very variable, negligible in some cases, and generally low. ${ }^{25}$ The IMF concludes that 'Tobacco excise revenues are generally low: 0 to 0.2 per cent of GDP in most subSaharan countries, 0.2 to less than 1 per cent of GDP in the Organisation for Economic Cooperation and Development countries and many large developing markets such as Vietnam or the Philippines, and slightly more in some large middle-income markets such as Egypt (1 per cent of GDP) and Turkey (1.4 per cent of GDP)' (IMF 2016: 1). There is, however, wide variation. Over the past century, excise taxes on tobacco and alcohol have been significant revenue sources in a number of countries, especially in East and Southeast Asia. In such cases, the retailing of tobacco and alcohol typically was a state monopoly. That, in turn, explains why excise rates on - and revenue from - tobacco and alcohol are low in most of sub-Saharan Africa today: the large transnational corporations that dominate the production and supply chains invest significant resources in lobbying and other political activities to persuade governments that it would be harmful to put significant taxes on tobacco or alcohol. Public policy in small poor countries is especially vulnerable to well-funded political influencing activities. The main argument that lobbyists use is that, especially in the case of cigarettes, higher excise taxes would simply lead to smuggling from neighbouring countries and thus loss of government revenue. Research shows both that the arguments about the danger of smuggling are much exaggerated, and that, at least in the recent past, the large transnational tobacco companies have themselves sometimes been complicit in smuggling. ${ }^{26}$ A degree of harmonisation in excise tax regimes among groups of neighbouring countries would further reduce the incentives to smuggle.

In contemporary low-income countries, consumer spending on commercial tobacco and alcohol products is still relatively low. It is, however, increasing fast, especially in Africa. The analysis of experience from elsewhere suggests that, for tobacco in particular, levying significant taxes only curbs consumption in the long term. In most poor countries, ministers of finance could double excise taxes on tobacco without running the risk that this would lead to a reduction in revenue levels within the following decade - and possibly much longer - but with the promise of important improvements in public health over the long term. In the case of tobacco, in particular, there is potential political support for raising taxes - domestically from health professionals and ministries of health, and internationally from global networks of tobacco control organisations, most of them connected to the World Health Organisation.

\subsection{Exemptions}

There is widespread agreement among tax specialists that governments in general, and especially governments of low-income countries, give away too much revenue by granting excessive tax exemptions to investors, both foreign and domestic. The specialists have been arguing that case for many years. The IMF, OECD, UN and World Bank have recently produced a joint statement on this issue (IMF et al. 2015). But it seems likely that exemptions are being used more, rather than less, frequently in low-income countries (Abramovsky et al. 2014; Keen and Mansour 2009). For a range of reasons, we do not have very reliable estimates of the actual revenue foregone through the granting of tax exemptions. The figures are however large: the OECD recently assembled data relating to six countries in Africa that suggested that the value of tax exemptions on average amounted to 33 per cent of taxes actually collected (OECD 2013).

\footnotetext{
$24 \quad$ There is a very large literature on this topic. This section is based in particular on IMF (2016); National Cancer Institute (2017); Savedoff and Alwang (2015); Van Walbeek et al. (2013); World Bank (2017).

Figures for some African countries are in African Tax Administration Forum (2017: 58).

See <http://www.tobaccotactics.org/>.
} 
Tax exemptions for investors are unlikely to disappear. There are valid cases for exemptions, provided they are used carefully and strategically. If exemptions were being used strategically, whether to attract investment in general or to focus it on certain sectors and activities, the process would involve:

- Granting them only on the basis of clear criteria and agreed, transparent procedures, through a single channel.

- Placing time limits on all exemptions.

- Monitoring their use and effects, ideally transparently as part of annual budget processes.

- Ensuring that all exemptions and their beneficiaries were registered with the tax administration, so that the enterprise could be taxed after the expiry of exemptions.

In practice, these procedures are often not followed. That is no surprise. We know that attracting and steering investment are not the only reasons that governments grant exemptions. They are also widely used to reward political allies, to provide leverage over potential political opponents, and to raise money, both for private pockets and to fund elections and other political activities (Moore 2015). ${ }^{27}$ Foreign investors, in particular, are often quite skilled at persuading governments of poor countries that tax exemptions are required, even if they have already decided to invest. The threat that the investment will go instead to a neighbouring country can panic governments. For this reason, the harmonisation of incentive arrangements on a regional level could be very useful in shifting the balance of bargaining power in favour of governments.

Poor institutions, weak governance, inadequate infrastructure - and uncertainty about taxation regimes - are typically much bigger disincentives to investment than corporate tax levels in low-income countries. It is unlikely that lowering the tax rate can compensate for a bad investment climate. In surveys of investors conducted in seven African countries between 2009 and 2012, an average of 84 per cent of respondents said that the availability of tax exemptions had not affected their investment decisions (IMF et al. 2015). Before giving tax exemptions, governments should focus on improving the investment climate by tackling such issues as excessive regulation and red tape (e.g. for registering a business, or for construction permits); the quality of roads, ports, electricity, telecoms and other infrastructure; and the predictability of the tax and legal systems. If taxes were not waived and some of the revenue were used to help dissolve these obvious obstacles to investment, almost everyone might benefit.

\subsection{Implementing VAT $^{28}$}

Value added tax (VAT) has steadily become more important, and is now the largest single source of revenue for governments of low-income countries. It is however collected inefficiently. There is a standard measure, known in the jargon as 'C-efficiency'. In 2010, Cefficiency for VAT in high-income countries averaged about 60 per cent. This means that 60 per cent of potential VAT revenue was being collected. By contrast, the figure for low-income countries was less than 40 per cent - although it has been increasing steadily over time. The dominant reason for the VAT gap in Europe is that governments choose to exempt consumers from paying VAT on basic consumption items, notably food and clothes. We have much less consistent data for low-income countries. However, a wide range of observational evidence suggests that the (much bigger) VAT gaps are due in large part to a combination of

Therkildsen (2012) argues that the increasing competitiveness of elections has been a major driver for the multiplication of tax exemptions in Tanzania.

The research underlying this paragraph is summarised in Keen (2013). Note that there is an overlap between the exemptions discussed in the previous paragraph and VAT exemptions. 
(a) the use of a wide range of VAT rates for different products and services, (b) organisational failures in collection, and (c) the success of lobbying by business for VAT exemptions at some intermediate point in the production chain - such as exemptions for sports facilities and local production of motor tyres - rather than for final consumer items like food. These causes are mutually reinforcing: the greater the complexity of the VAT regime, the wider the scope for evasion. There is considerable scope to increase revenue collection by simplifying the structure of VAT systems and monitoring compliance more closely. The impact on income distribution is unclear, but the burden would certainly not fall entirely on final consumers. Businesses benefit in various ways from complex, 'leaky' VAT systems.

\subsection{Taxing the rich}

Rich people in poor countries typically pay low taxes on both their assets and their incomes. Sometimes, as for example in much of Latin America, this is because they have long experience of dealing with populist or leftist governments who have tried to tax them, and have developed sophisticated avoidance techniques - that often involve keeping assets offshore. In contemporary sub-Saharan Africa, the more common story is that tax collectors have generally not come after rich people in a determined way - because, it appears, of the power of political connections, patronage and collusion. This results in an increasingly obvious inequity in the distribution of the tax burden between rich and poor. In many African countries, and in other low-income regions, the numbers of the wealthy and the superwealthy seem to be growing fast (McCluskey 2016). So, too, as economies grow and populations continue to urbanise at a rapid rate, have the prices of one of the major assets held by the rich - real estate.

Research conducted by the Uganda Revenue Authority as part of its effort to begin to correct these anomalies gives some idea of the scale of the problem. For example, the researchers found that in 2013/14: among a sample of the sixty top lawyers in the country, only 35 per cent paid any personal income tax; only 5 per cent of company directors did so; and among seventy-one top ranking government officials, who owned enormous assets, including hotels, private schools and media houses, only one had ever paid personal income tax (Kangave et al. 2016). This is reflected in aggregate public revenue statistics. First, the total revenue yield from personal income taxes is much lower in poorer than in richer countries. Personal income taxes amount to an average of about 10 per cent of GDP in wealthy countries, but for only 2 per cent in sub-Saharan African countries (excluding South Africa) - see $<$ http://www.ictd.ac/datasets/the-ictd-government-revenue-dataset>). Second, in poorer countries, nearly all revenue from personal income taxes comes from withholding taxes on formal sector salaries. Revenue from taxes on income from professional self-employment (e.g. lawyers, private doctors, consultants, accountants and architects) and from property and other investments - the main income sources of the rich - is by comparison tiny. ${ }^{29}$

Meanwhile, there is mounting evidence that an extremely large share of African financial wealth is held offshore in tax havens. While such estimates are inevitably imprecise, the best such estimates, from Gabriel Zucman, suggest that at least 30 per cent of all African financial wealth is held offshore (Zucman 2015). This is higher than any global region other than Russia and the Gulf States, and implies that wealthy Africans, who are the only ones with wealth offshore, almost certainly hold significantly more than half of their financial wealth overseas. Zucman estimates tax losses of at least $\$ 15$ billion annually based on the failure to tax investment returns on those funds - about 0.5 per cent of GDP. Treating this as a lower bound, and considering other forms of wealth held abroad (property, art, jewellery, etc.), it is

29 The data that underpins this claim is scarce and scattered. The most recent version of the OECD's Revenue Statistics in Africa (OECD 2017) contains adequate data for five African countries: Ghana (p.176), Kenya (p.178), Rwanda (p.187), Swaziland (p.193) and Uganda (p.199). For those five countries, in 2015, withholding taxes collected by employers on the income of employees - Pay-As-You-Earn, or PAYE - on average accounted for $97 \%$ of total income tax collection from individuals. 
easy to imagine annual revenue losses of more than 1 per cent of GDP, quite apart from taxes foregone when the funds were first stashed offshore.

Some of these tax losses reflect the logistic and organisational - as well as political difficulties in taxing the rich. Taxing wealth held offshore could be straightforward if there were more effective international cooperation. Domestically, it is often difficult for tax administrations to identify and verify the income that wealthy people earn from selfemployment and investment. However, if tax administrations could overcome some of the political barriers to action, significant increases in revenue would be quickly attainable. Meanwhile, the status quo risks becoming increasingly strained as poorer citizens continue to bear heavy tax burdens, and come to realise the tax privileges enjoyed by the comparatively wealthy.

\subsection{Property taxes ${ }^{30}$}

Land and property are among the most visible indicators of personal wealth. Because they are easily identified and immovable, they are potentially easily taxed. And in many lowincome countries, urban-centric economic growth and continued urbanisation mean that urban real estate values have grown fast, generating enormous unearned wealth for property owners (Goodfellow 2015). Despite being widely recognised as an economically efficient and progressive revenue source, property taxes are much underused in virtually all low-income countries. This is perhaps the most visible example of the failure of governments to tap potential revenue collection, particularly from the wealthy.

In most OECD countries, property taxes account for 1-2 per cent of GDP, while in East Asia they are sometimes larger still. Reliable figures on property tax collection in sub-Saharan Africa are rare. In most countries for which we have useable figures, collection amounts to only 0.1-0.2 per cent of GDP. It seems likely that levels are often similar, or lower, in countries where no data is available. ${ }^{31}$

The weakness of property taxes has sometimes been attributed to the technical difficulty of maintaining complete and up-to-date registers of property values. This is certainly a challenge, but a small one when compared to the difficulty of tracing the income and wealth of rich people, or deconstructing the tax accounts of transnational corporations. There are two deeper reasons for the poor performance of property taxes in low-income countries. The first is that systems of property taxation inherited from the colonial period involve unnecessarily complex valuation methods, and fragmented administrative arrangements. The second stems from the simple logic of politics. Effective property tax systems bear relatively heavily on economic and political elites, who have used their power to frustrate reform. Perhaps the best evidence on the nature of these barriers is a growing number of local success stories where property tax revenue has expanded rapidly - albeit from extremely low bases - as a result of concerted political and administrative commitment (Cheeseman and de Gramont 2017; de Gramont 2015; Jibao and Prichard 2016; Goodfellow and Owen 2018).

Existing property tax systems are generally based on sending professional property valuers to estimate the market or rental value of every property. That value forms the basis of the tax

30 We focus here on the most common kinds of property tax: recurrent charges on the owners or occupiers of real estate. There are, however, two other ways of taxing property that might be equally useful, according to circumstances: (a) income taxes on the income earned from renting out property, and (b) taxes on the sale or legal transfer of property ownership. The literature on property taxes in low-income countries is large. Bahl et al. (2008) and Bird (2010) provide a good introduction.

While it is common to see sources suggesting levels of property tax collection in developing countries closer to $0.5 \%$ of GDP, these figures appear skewed sharply upward by (a) reliance on high-performing countries for which data is available in international datasets, and (b) definitional issues that include revenue other than the recurrent property taxes that are of greatest interest. 
liability. There are far too few skilled valuers, while the task itself is enormously difficult owing to the absence of public information on market and rental values - and, in some cases, ambiguity about the ownership of properties. Yet recent experiences point towards relatively straightforward options for improvement: (a) simplify the assessment of property values, through the use of methods that rely primarily on observable features of properties to assess value; (b) decentralise responsibility for property valuation away from central valuation offices, in order to facilitate the hiring and training of adequate valuers; and (c) where necessary, simplify institutional responsibility for property tax collection, such that it is concentrated in the hands of authorities with strong incentives to collect significant revenue. While the resultant valuations would lack the conceptual refinement and apparent precision of existing systems, they would in practice offer improved revenue collection and fairness through widening the base on which property taxes are levied.

\subsection{Turning government organisations into better tax citizens}

Most discussions of taxation assume a basic distinction between, on the one side, taxpayers, and, on the other, the agency which is doing the taxing - government. For contemporary lowincome countries, that distinction can, from a policy perspective, be misleading.

Governments are not unitary entities. They comprise networks of organisations that may be more or less coordinated or competitive. Those government organisations primarily responsible for collecting revenue may have limited authority over the others. The others have influence over the tax system in their roles as direct tax payers and as tax collection intermediaries, and because collectively they typically constitute the largest purchaser in any national economy. They can often use this influence to bypass or reshape standard tax procedures, and thereby reduce the tax take. ${ }^{32}$ The problems include:

- Long delays in remitting to the tax authority or to the central government treasury: the taxes that they are liable to pay directly (e.g. import duties, VAT on their purchases); the taxes that they are licensed to collect directly (e.g. motor vehicle licence fees, royalties on natural resource extraction); or the taxes that they collect as intermediaries (e.g. the personal income taxes of government employees that are deducted at source under PAYE arrangements, withholding taxes on public sector contracts). This may be compounded by successfully putting pressure on government to periodically write off all public sector tax arrears. The motivation for delays may be either to increase organisational budgets, or to permit people in key accounting positions to use the money to play in financial markets for personal gain.

- Declining to provide the tax authority with the information it would need - and which it might require private companies to supply - to properly assess tax obligations. This might include: information on the non-salary benefits given to public sector employees that are formally taxable; sufficiently detailed personal information on those employees so that the tax authority could correlate earnings from their formal salaries with earnings from other sources; or automatic notice, with details, of the identity of recipients of (large) public sector contracts.

- Refusing to participate in charging or paying VAT, thus compromising the information chain on which effective VAT collection depends - and worsening the problem of inefficient VAT collection mentioned above.

Government is itself a taxpayer, and often a bad one. There is considerable scope to increase the tax take by turning government organisations into better tax citizens.

\footnotetext{
There is very little consistent analysis of this problem, but reason to believe that it is significant. The most comprehensive available source of direct information is in the ICTD Annual Lecture, delivered by Henry Saka, Commissioner for Domestic Taxes, Uganda Revenue Authority, at Entebbe on 17 October 2017. This will be published by the ICTD. Note also that these problems tend to be particularly significant in countries that are large mining or energy exporters. State corporations responsible for the extractive sector often act as a 'state within a state', setting their own rules for tax, accounting, procurement and other fiscal activities (de Oliveira 2007; Vines et al. 2009).
} 


\section{Improving organisational performance}

Having identified specific potential sources of additional revenue, we now adopt a different perspective on the same broad question: what is the scope for obtaining additional revenue by generally improving the organisational performance of tax administrations themselves? What are the likely returns to performing more effectively and efficiently all those mundane activities that tax collection involves, such as: maintaining accurate taxpayer records; making it easy for taxpayers to comply; ensuring that filing and payments are done on time; encouraging different parts of the organisation to share information and cooperate; resolving tax disputes simply and cheaply; identifying and collecting arrears; recruiting and promoting staff on merit; providing adequate staff training; closely monitoring staff for wrong-doing; sanctioning them effectively; and ensuring that all revenue collected is accounted for and transferred to the national treasury? And are there particular activities that deserve special attention?

There are good reasons to believe that the scope for improving organisational performance is high. Let us begin with a broadly deductive argument. Until recently, most tax authorities in low-income countries neither published much information on their own performance, nor undertook much analysis of it. ${ }^{33}$ We know of a revenue authority in Africa that will provide no more information on its performance to its own Ministry of Finance than the amount of money it collects each year by type of tax. At the same time, tax administrations enjoy considerable potential coercive power, over both ordinary taxpayers and potential critics, for example, in the legislature or the private sector. They can always justify an intensive audit of a business or individual taxpayer, and ensure that the process is painful and/or expensive to the recipient. Experience tells us that any organisation that combines (a) a guaranteed income, with (b) the potential to intimidate individual citizens and businesses, and (c) weak public accountability, will be tempted to abuse that situation. Both corruption and organisational laziness will likely result.

It is hard to get close to the facts about levels of corruption. The information available on the organisational performance of tax authorities in low-income countries has until recently been limited and largely anecdotal. Some of the most reliable and consistent information came from overviews by IMF staff - see, for example, Fossat and Bua (2013), Kloeden (2011) and Zake (2011). ${ }^{34}$ All these reviews suggest that there is considerable scope for improvement. However, the poor performers are never identified. This fog over the performance of tax administrations is now beginning to lift. In particular, we now have the first trickles of what are likely to become steady streams of information through what is known as the Tax Administration Diagnostic Assessment Tool (TADAT) process. TADAT is a cooperative international initiative. ${ }^{35}$ The TADAT Secretariat has developed and field-tested a diagnostic tool that involves teams of trained assessors visiting national tax administrations in lowincome countries and scoring them on twenty-eight separate performance indicators. As of September 2017, forty-one national assessments had been completed. The reports are confidential, and published only with the consent of the government concerned. To date, only seven have been published - for Armenia, Georgia, Jordan, Kyrgyz Republic, Liberia, Peru and Zambia. Overall, the grades received by these seven tax administrations are low: 18 per

\footnotetext{
33 For a comparison, see the occasional analytic reports published by the OECD under the title of Tax Administration. However, the African Tax Administration Forum (ATAF) is beginning to produce something similar for Africa (African Tax Administration Forum 2017).

$34 \quad$ For reasons we need not explore here, league tables comparing countries in terms of tax administration - notably the World Bank and PwC annual Paying Taxes - are neither very reliable or useful.

Note also another recent cooperative international initiative to collect more consistent data on tax administration and make it publicly available: International Survey on Revenue Administration (ISORA), which emerged from Revenue Administration's Fiscal Information Tool (RA-FIT).
} 
cent of scores were As, 19 per cent Bs, 35 per cent Cs and 28 per cent Ds. This is consistent with the general impression of widespread underperformance. ${ }^{36}$

We were also able to use some anonymised data relating to all forty-one completed TADAT assessments to test a proposition that the IMF had put forward in 2015: that tax authorities have been better at using digital technologies to introduce highly visible taxpayer services (facilities to file tax returns and to pay tax bills online) than at using them in core business processes (managing and accounting for tax revenue receipts), which are central to both efficiency and to the prevention of dishonesty. ${ }^{37}$ The data confirms the proposition. ${ }^{38}$

The effective gathering and sharing of data lies at the heart of effective tax enforcement. Yet, despite spending huge sums on new IT systems, many tax administrations still do not routinely pool and share data internally between different units (IMF 2015: 39). Frequently, data collected by Customs is not routinely shared with, or compared to, data collected by units collecting, for example, personal income taxes, corporate profits taxes or VAT. Sometimes this reflects dysfunctional, overlapping and poorly designed IT systems (Box 2). ${ }^{39}$ However, this dysfunction, and the broader failure of many IT systems, seems to have deeper roots. While sophisticated IT systems have been designed to achieve improved sharing and deployment of taxpayer data, this sharing could be achieved easily enough using a USB stick to transfer key data - at least about larger taxpayers - manually from one department to the next. The reasons that information is not shared more widely seem more related to unwillingness and distrust than to lack of technology or know-how. The same could be said, it seems, of the absence in many cases of concerted pursuit of non-compliant taxpayers and defaulters, ${ }^{40}$ basic protocols for monitoring staff performance, or more effective accounting of revenue.

\section{Box 2}

We know of a revenue authority in a low-income country that uses four IT systems to manage taxpayer information. System $A$ is supposed to be the only means of generating Taxpayer Identification Numbers (TINs) and recording tax payments. System $A$ was originally introduced to replace System $B$. However, the migration from $B$ to $A$ was never completed after it was realised that $A$ cannot perform some functions. Each is currently used to manage a large number of taxpayers. A is used mainly for personal and corporate income tax, and withholding tax. The two systems are not interfaced, and are managed by different departments. The information on them often conflicts. System C was introduced to replace System D, which was used to record VAT transactions. Although the revenue authority no longer recognises System D, some stations still use it and the Large Taxpayer Office uses it as a backup. Because the four IT systems are not interfaced, some work is duplicated. The information on any one taxpayer is dispersed: registration details might be on one system, VAT payments on another, and income tax payments on a third. Staff with authorisation to use one system need to obtain permission from another department to access another system. TINs are supposed to be issued only through System A. However, some taxpayers have more than one TIN - which enables them to avoid some tax. Some are issued temporary TINs that are not recorded on any system.

We are assuming that this sample of seven countries is broadly representative. Note that the figures for these countries are biased upwards by the outstanding performance of Peru's revenue authority, SUNAT. SUNAT received an A on 15 of the 28 items, and accounted for $43 \%$ of the A scores received by all 7 countries.

37 'Good progress has been made in developing front-end electronic interfaces for taxpayers, but back-end developments have lagged significantly, for example in automated risk profiling, joined-up filing and accounting across taxes, and matching with third party data' (IMF 2015: 39).

38 The data was kindly made available to us by the TADAT Secretariat. They are the original, anonymised country scores for three TADAT variables. We converted the TADAT rankings into quantitative scores by giving 4 points for an A score, 3 for a B, 2 for a C, and 1 for a D. The average score, for the 41 tax administrations, on variable P8-23 Adequacy of Tax Revenue Accounting System was 2.0. Higher scores, suggesting relatively more investment and effort, were obtained on P4-11 Use of Electronic Filing Facilities (2.1) and P5-12 Use of Electronic Payment Methods (2.4).

39 This relates to the broader problem of the high failure rate of large ICT reforms in public administration in many countries.

40 The limited information we have for African tax administrations suggests a high ratio of tax arrears to collection (African Tax Administration Forum 2017: 130-3). 
There are three broad messages for reformers:

- Relative to other organisational domains, many potential improvements in tax administration require neither significant financial expenditure nor large improvements in technical expertise. Instead, they demand only a political commitment to improvement strong enough to overcome vested interests among taxpayers, politicians and tax administrators themselves. ${ }^{41}$

- To be effective, a tax administration needs both a supportive institutional environment especially in respect of the law and judicial system - and cooperative relationships with a range of other organisations that can provide third-party information to help cross-check the validity of tax returns filed by individuals or companies. Utility companies can provide useful information on the consumption of electricity or water; the motor vehicle licensing authority on motor vehicle ownership; banks and other financial institutions on ownership of liquid assets; and the property registration authority on property ownership. It is hard to achieve significant, sustained improvements in the organisational performance of tax administrations without corresponding improvements in the institutional environment in which they operate. That is one reason why dramatic, sustained increases in the organisational performance of tax administrations are rare.

- There may be some genuinely low-hanging fruit to be plucked - organisational practices that are widespread, inefficient, but not serving any strong vested interest. For example, in Africa we frequently encounter tax administrations that expend considerable resources in registering potential taxpayers, but then find they have on their books large numbers of clients who either do not file tax returns or file returns indicating the absence of business activity or repeated financial losses. Little revenue is generated. A more businesslike approach to registering and de-registering potential taxpayers might be beneficial all round.

\section{Changing tax policies}

Our central question is: how can governments of low-income countries increase the tax take? Section 1 provides one answer: by focusing on developing specific, under-exploited revenue sources. Section 2 supplies another: by improving the organisational performance of tax authorities. In this section we offer a third answer: by trying to change tax policies, both nationally and internationally, to better adapt them to the taxation circumstances of lowincome countries. Our goal here is not to review the entire range of tax policy questions facing low-income countries, nor to enter into contested debates about whether the rates for particular taxes should be higher or lower. We rather highlight a few areas in which we believe there could be significant payoffs from broad policy change.

\subsection{Tax companies more on turnover, and less on reported profits}

It is one of the core features of contemporary tax systems that business contributions to the public treasury should as far as possible be levied on their profits, and not on measures of turnover or sales. The simplified economic argument for this is powerful: the more that companies are taxed on turnover, the more likely it is that they will be obliged to pay taxes even when their profits are low or they are making losses. That in turn would lead to reductions in overall levels of investment and economic activity, leaving everyone worse off.

These incentive effects of taxation are important. There are, however, potential trade-offs between economic efficiency and governments' need to raise revenue. Profit-based taxes

$41 \quad$ Anecdotal evidence suggests that politicians and other external actors often play a role in undermining the organisational integrity of tax administrations. 
are more attractive to firms, but are significantly more difficult for governments to enforce than taxes on turnover. This is especially true when companies are part of a transnational group, and tax administrations have limited capacity. As we explained above, in these circumstances companies are better able to artificially reduce locally declared profits through transfer mispricing, or by inflating costs. Where governments are able to enforce them effectively, profit-based taxes are preferable because they improve economic efficiency. However, where enforcement capacity is weak, the efficiency benefits of profit-based taxes may be significantly outweighed by the consequent failure to tax corporate profits adequately. Worldwide, about twenty governments have made legal provision for using a tax on corporate turnover (i.e. gross revenue, sales), typically levied at around 1 per cent, as an alternative to a corporate profit tax. ${ }^{42} \mathrm{~A}$ recent empirical study of just such a tax in Pakistan the Alternative Minimum Tax - concludes that it reduce evasion by almost 70 per cent, without any loss of economic efficiency (Best et al. 2015).

There is, therefore, a good case for governments to consider the wider use of taxes levied on corporate turnover rather than profits. This is especially likely to make sense when:

- It is easy for companies to practice transfer mispricing. Large telecoms companies that have operations in adjacent countries constitute a classic case. In some countries they are already taxed in this way (Durst 2015). The argument for taxing mining companies more through royalty-like arrangements (Section 1) is a special case of the same general argument.

- Companies are engaged in predictable, routine, low-risk activities on behalf of a foreign principal: distributing branded consumer goods; manufacturing on contract; and operating call centres or data processing facilities. The risks that turnover taxes will discourage investment are small.

None of these variants of turnover taxes are without problems. Arrangements may need to be made to deal with loss-making situations. But all taxes in practice are adapted for special cases and unusual situations. Indeed, turnover taxes may become more common even in higher-enforcement OECD countries, as governments struggle with the problem of taxing the (elusive and mobile) profits of large IT companies. In 2016, the British tax authorities reached an agreement with Google that the company would pay tax in Britain on the basis of its revenue from UK advertisers, not its profits from advertising. The European Union is currently developing a proposal for internet-based companies like Google and Amazon to pay tax on the basis of the revenue they earn in EU countries.

\subsection{Beware of tax treaties}

Until recently, it was common for governments to sign bilateral tax treaties in the belief that this was essential to encourage investment. It was argued, for example, that Belgian companies would not invest in Morocco unless there were a bilateral tax treaty between Belgium and Morocco to ensure that Belgian investors would be adequately treated in tax terms. In recent years, the term 'abusive tax treaties' has become increasingly common. It has become more evident that tax treaties are often not needed to ensure foreign investment, and that those in place - around 4,000 in all - are often quite disadvantageous to the country receiving investment (Action Aid 2016; Hearson and Kangave 2014; IMF 2012). In many cases governments have signed away the right to levy taxes on inward investors, including capital gains taxes and a range of withholding taxes, while in some cases these treaties have also opened up avenues for aggressive strategies for shifting profits into tax havens. Through the Multilateral Convention to Implement Tax Treaty Related Measures to Prevent Base Erosion and Profit Shifting, the OECD is currently organising a process to try to remove abusive clauses from existing tax treaties. The best general advice for low-income

42 Information kindly provided by Michael Durst in a private communication. 
countries is to actively review existing tax treaties, while being very careful before signing any new ones.

\subsection{Act regionally on tax exemptions and international tax rules}

A defining feature of many of the tax challenges facing low-income governments is that they cannot be effectively confronted by countries acting independently, but demand more concerted regional action. The most striking example is tax exemptions, a classic beggar-thyneighbour policy problem (Section 1). International investors frequently pit neighbouring countries against one another, placing each under pressure to offer bigger exemptions in order to attract investment. In the short term, governments are persuaded that providing tax exemptions will bring them additional investment. In the long term, however, this process drives effective tax rates down everywhere. All countries are left with reduced public revenue. The potential solution lies in regional coordination around the terms and processes through which any tax exemptions can be awarded. Though politically daunting, this is not impossible. The European Union, for example, has rules limiting the use of exemptions by its members to compete for investment, while the East African Community has made significant progress in advancing broader tax cooperation. Meanwhile, regional cooperation could also bear dividends in other areas, including common rules on transfer pricing and cooperative approaches to taxing telecoms, tobacco and alcohol. For example, if all countries in a region harmonised their transfer pricing rules, this would reduce the transaction costs of the taxation process for both tax administrations and investors. ${ }^{43}$

There is a similar case for more regional cooperation in relation to the reform of international tax rules. The negotiation of international rules is dominated by the OECD. Relative to the UN Tax Committee, the OECD has the great advantage of being authoritative. It is able to get things done relatively quickly if there is adequate agreement among its members. But those members are all rich countries. Non-members may be consulted extensively, and invited into meetings. But they ultimately have no vote. However, we believe that a significant shift is underway in global tax politics. In 2013, the G20 charged the OECD to take control of what was known as the base erosion and profit-shifting (BEPS) process, and gave them two years to come up with solutions to transnational tax evasion and avoidance. In historical terms, charging rich industrial countries to come up with an action plan for the world appeared to be a rather regressive step. It has elicited enormous and consistent criticism. Yet in practice the OECD - sensing a threat to its long-term position due to the growing power of non-OECD countries - has been unexpectedly proactive in involving non-members deeply in its tax-related debates. After reporting on BEPS in 2015, the OECD has taken the lead in stimulating collective international action to revise abusive tax treaties, and to improve the exchange of tax information among national tax administrations.

The status quo undoubtedly remains far from perfect. But threats to the institutional dominance of the OECD have resulted in low-income countries enjoying more bargaining power in relation to the international tax system than they have ever known. If they act collectively, they have the possibility of using it to push for reforms that are more appropriate to their taxation circumstances. These might include, among other possibilities, greater openness to alternatives to traditional approaches to transfer pricing, expanded transparency of country-by-country financial accounts of transnational companies, greater transparency about the beneficial ownership of shell corporations, improved access for low-income countries to information about wealth held abroad by wealthy citizens, and greater legal cooperation in addressing wealth held abroad.

43 The African Tax Administration Forum, OECD and World Bank are currently working to harmonise transfer pricing rules within the Economic Community of West African States (ECOWAS). 


\subsection{Improve the tools for taxing the wealthy}

We noted above that perhaps the most important step towards more effectively taxing the wealthy is technically the simplest: improve the sharing of data within tax administrations to identify avoidance and evasion. The next step is likely to lie in also accessing data from parallel organisations that can be used for tax enforcement. This is in part a question of organisational performance, but it is likewise a question of policy reform: in many countries laws either prevent the sharing of such information, or are ambiguous about its legality (thus offering a convenient scapegoat for a lack of action). While not a silver bullet for improvements, simple legal changes to facilitate the sharing of third party data, coupled with organisational commitment to use the data, could yield significant gains in revenue and equity.

Some data sharing should take place among government agencies. This would likely include data from property registries, motor vehicle registrations, utility companies, business registrations or government contracts (particularly where withholding taxes are not applied on those contracts). Access to such information on income, assets and spending can offer useful clues about potential tax evasion. Meanwhile, other information should come from third-party actors outside government - including stock exchanges, company registrars, banks and credit card companies - and from tax administrations overseas. Access to such data is the norm in OECD countries, but has only slowly been introduced in lower-income countries, either owing to worries about data privacy, simple oversight, or as an indirect way of preventing effective taxation of the wealthy. As with data sharing within tax agencies, progress in this area not only holds significant potential, but may also act as a litmus test for broader commitment to tax reform.

\section{Politics}

One obvious objection to the preceding discussion is that it is naïve, because the greatest barrier to improved taxation is not a lack of knowledge, but a lack of political support for reform. Certainly, politics lies at the root of most taxation challenges. The essence of taxation is that government agents approach citizens and business people with demands that they hand over a proportion of their income or assets with little or no guarantee that any of the resources collected will be used for the (visible) benefit of the taxpayer, their family, their occupational group, their business, or the area where they live. Such an extractive relationship is intrinsically political.

But it is not obvious that it is inherently more difficult for governments to raise revenue than to regulate electricity providers, keep armed forces under control, or maintain macroeconomic stability. Governments are in general rather good at capturing income flows. Every year, they transfer something like a quarter of global income into public treasuries - without generating much conflict. Political barriers are not insurmountable - but the belief that they are can become a convenient excuse for inaction. Indeed, it is likely that the potential for revenue-raising through the measures discussed here - notably, the taxation of the rich has been under-rated by reformers because it is believed to be politically too difficult. But if they fail to tackle high profile and visible areas of tax non-compliance, governments risk reinforcing a lack of trust in tax systems, and thus further raising the political barriers to reform.

In seeking to confront political challenges, there are some general features of tax politics that any potential reformer might bear in mind: 
- Governments have learned routinely to offer something in return for tax compliance, especially to groups that might otherwise find it easy to avoid or evade. This 'something' may be public services, policies favoured by particular groups, or complicity in the undertaxation of some kinds of people and activities. Taxpayers may grudgingly comply with tax demands because experience shows that they can expect something in return. As importantly, they may offer the political support needed to confront vested opposition to some kinds of taxation when they see that they receive some return for their tax compliance. Most of the time there is some kind of implicit social contract underpinning successful expansion of taxation.

- There is also mounting evidence of the value to taxpayers of perceived fairness in the assessment and collection of taxes. There are three broad dimensions of fairness: redistributive fairness (tax burdens are distributed fairly among taxpayers); procedural fairness (taxes are collected according to the law); and retributive fairness (penalties for non-compliance are fair, and fairly applied). Improvements in fairness potentially play an important role in mobilising support for reform, and increasing voluntary tax compliance.

- Historically, in many low-income countries tax reform has been the preserve of experts. It is often believed that discouraging public debate allows new taxes to be introduced without permitting sufficient time or space for significant opposition to arise. This has often worked well: large-scale changes to tax systems, led by the introduction of VAT, were often carried out with limited public opposition in the 1980s and 1990s. However, this approach appears decreasingly effective. While secretive processes may forestall broad public opposition, they also rule out the possibility of broad popular support from those who would benefit from broader taxation and expanded public spending programmes. Without such support, little progress has been made in overcoming resistance to taxing economically and politically powerful individuals, and reform is more likely to be captured by increasingly organised interest groups. Opening up tax debates and more clearly linking tax to visible benefits - is likely to be more effective.

- Much of the time, the politics of taxation are rather like the notorious trench warfare in Europe during World War 1. Both sides are well dug in. Each employ similar instruments, and have long experience of the tactics employed by the other, and ways of countering them. Major initiatives may sometimes lead to significant breakthroughs, but most often they are blunted, thwarted and perhaps reversed. Big, sustained changes in the balance of power are rare. Tax policies and patterns of tax collection tend to be sticky: they normally change only incrementally from year to year. Significantly increasing the tax take typically involves a long slog, as well as significant opportunism in taking advantage of favourable moments for reform.

- The politics of taxation interact with the organisational capacity to tax effectively. Tax authorities that suffer low organisational capacity find it very hard to brush aside political objections to their attempts to do their job. Conversely, those tax authorities that have a reputation for competence and for reliably delivering revenue do not live in fear of every politician who has good connections to the president or prime minister. They have some autonomy from political pressure. They are likely to obtain more generous operating and capital budgets, to retain good staff, and to acquire the resources to train them (Strauss 2008). The existence of institutions that practice sensible tax policies and collect revenue effectively and efficiently helps to shift the balance of political forces in favour of more taxes and/or tax reform. It is not helpful to pose 'getting the politics (of tax reform) right' or building up institutional tax capacity as alternatives. They are likely to be mutually reinforcing.

The fact that taxation is very political does not mean that increasing the tax take or reforming the revenue system are unusually challenging tasks. Successful reform will typically involve a great deal of hard, steady work, and the gradual, iterative construction of trust in the tax administration. A capable tax administration can be just as valuable an ally as a political party, social movement or lobbying group. 


\section{Conclusion}

The suggestions presented here are not intended as a checklist for reformers, nor as an exclusive guide to reform priorities. At any moment in time there might be better ways of increasing the tax take. Our hope is that this paper might nonetheless support creative thinking about potential opportunities. It seems reasonable to think first about where there is, in principle, significant revenue to be tapped, and to ask what options might be available for doing so. With these potential targets in mind, reform programmes can then seek to combine creative administrative and policy reforms for expanding the tax take. These reform strategies are likely to be very diverse, but recent research and experience has pointed towards some potentially underexploited options, which we have tried to highlight here.

In concluding it seems useful to address a question that hovers over recent reform debates: a domestic or an international focus? When seeking additional revenue, how far should the governments of low-income countries be looking to reform domestic tax policies and administration, and how far should they be focused on reform of international tax rules, and the taxation of transnational firms and individuals? The past decade has witnessed an upsurge in attention to the international dimensions, driven by growing - though sometimes overstated - evidence of significant tax evasion and avoidance by transnational companies and wealthy individuals (Section 1). The problem is substantively important and morally galling. The wealthiest and most powerful members of society are among the main beneficiaries. They have been knowingly aided and abetted by the governments, corporations, banks and professional organisations of some of the most wealthy countries. There are good reasons why advocacy has focused on these 'tax justice' concerns. Contrary to the initial pessimism of many observers, the campaigners have helped stimulate important reforms in the international tax system.

The question is thus not whether this experience has been valuable. It clearly has. It is rather: what to do next? On the one hand, there are good reasons to continue to focus on international tax issues. While recent reforms have helped, the international tax rules remain far from optimal for low-income countries: transfer pricing rules remain extremely difficult to enforce; access to country-by-country corporate accounts is imperfect; and access to information of wealth held abroad by citizens remains difficult, or impossible, for tax authorities with limited capacity. Continued effort on the international front is essential. But there is also a risk of allowing the moral outrage around international evasion and avoidance to pull attention away from the more banal, but perhaps ultimately more important, work of building domestic tax systems. In aggregate revenue terms, it is difficult to avoid the conclusion that the largest dangling fruits are largely domestic. The best estimates of both revenue losses from transfer mispricing and the failure to tax individual wealth held offshore are on the scale of 1-2 per cent of GDP each. These are large magnitudes, but still represent only a small portion of the potential additional revenue highlighted in this paper. Revenue lost due to a simple lack of enforcement of income taxes on the wealthy, ineffective property taxation, overly generous tax exemptions, collusion and poor enforcement in the mining sector - not to mention basic questions around enforcement of VAT and customs duties - is likely significantly larger in the long term. As important, building robust and broad-based revenue systems domestically is likely to be an essential ingredient to fully confronting international sources of evasion. While stronger international tax units, basic policy reforms, or the adjustment or repeal of tax treaties, are able to capture low-hanging fruit in confronting the most egregious of abuses, more systematic gains - and the prosecution of high net worth individuals with wealth held abroad - will depend on strengthening revenue systems generally. The choice between an international or domestic focus is to a large extent false: progress in one domain is dependent on advances in the other. 


\section{References}

Aarsnes, F. and Lundstol, O. (2013) The Case for Windfall Taxes. A Guide to Optimal Resource Taxation, Oslo: Publish What You Pay, Norway

Abramovsky, L., Klemm, A. and Phillips, D. (2014) 'Corporate Tax in Developing Countries: Current Trends and Design Issues', Fiscal Studies 35(4): 559-588, doi: 10.1111/j.14755890.2014.12042.x

ActionAid (2016) Mistreated. The Tax Treaties that are Depriving the World's Poorest Countries of Vital Revenue, Johannesburg: ActionAid International

Africa Progress Panel (2013) Africa Progress Report 2013. Equity in Extractives: Stewarding Africa's Natural Resources for All, Geneva: Africa Progress Panel

African Tax Administration Forum (2017) African Tax Outlook 2017, Pretoria: African Tax Administration Forum

Bahl, R., Martinez-Vasquez, J. and Youngman, J. (eds) (2008) Making the PropertyTax Work. Experiences in Developing and Transitional Countries, Cambridge MA: Lincoln Institute of Land Policy

Best, M., Brockmeyer, A. Kleven, H., Spinnewijn, J. and Waseem, M. (2015) 'Production versus Revenue Efficiency with Limited Tax Capacity: Theory and Evidence from Pakistan', Journal of Political Economy 123(6): 1311-1355

Bird, R. (2010) Subnational Taxation in Developing Countries. A Review of the Literature, Policy Research Working Papers, Washington DC: World Bank

_ Martinez-Vasquez, J. and Torgler, B. (2008) 'Tax Effort in Developing Countries and High Income Countries:The Impact of Corruption, Voice and Accountability', Economic Analysis and Policy 38(1): 55-71

Cheeseman, N. and de Gramont, D. (2017) 'Managing a Mega-City: Learning the Lessons from Lagos', Oxford Review of Economic Policy 33(3): 457-477, doi:

10.1093/oxrep/grx033

Collier, P. (2010) 'Principles of Resource Taxation for Low Income Countries', in P. Daniel, M. Keen and C. McPherson (eds), The Taxation of Petroleum and Minerals: Principles, Problems and Practice, London and New York: Routledge/International Monetary Fund

Daniel, P., Keen, M. and McPherson, C. (2010) The Taxation of Petroleum and Minerals: Principles, Problems and Practice, Routledge explorations in environmental economics, London and New York: Routledge/International Monetary Fund

— Swistak, A. and Thuronyi, V. (eds) (2016) International Taxation and the Extractive Industries, London: Routledge

de Gramont, D. (2015) Governing Lagos. Unlocking the Politics of Reform, Washington DC: Carnegie Endowment for International Peace 
de Oliveira, R. (2007) 'Business Success, Angola-style: Postcolonial Politics and the Rise and Rise of Sonangol', Journal of Modern African Studies 45(04): 595-619, doi: doi:10.1017/S0022278X07002893

Durst, M. (2016) Improving the Performance of Natural Resource Taxation in Developing Countries, ICTD Working Paper 60, Brighton: International Centre for Tax and Development

- (2015) Limitations of the BEPS Reforms: Looking Beyond Corporate Taxation for Revenue Gains, ICTD Working Paper 40, Brighton: International Centre for Tax and Development

EY (2014) Complexities, Challenges and Opportunities of Supply Chain Management in Africa, EY Africa Tax Conference

Fauvelle-Aymar, C. (1999) 'The Political and Tax Capacity of Government in Developing Countries', Kyklos 52(3): 391-413

Forstater, M. (2017a) How Big is the Transfer Pricing Prize for Development?, Center for Global Development, 18 August, <https://www.cgdev.org/blog/how-big-transfer-pricingprize-development>

(2017b) Illicit Financial Flows and Trade Misinvoicing: Time to Reassess, 7 September, Center for Global Development, 1 September, <https://www.cgdev.org/blog/illicitfinancial-flows-and-trade-misinvoicing-timereassess?utm_source $=170906 \& u t m \_$medium $=$cgd_email\&utm_campaign=cgd_weekly \&utm_\&\&\&>

Fossat, P. and Bua, M. (2013) Tax Administration Reform in the Francophone Countries of Sub-Saharan Africa, Washington DC: IMF

Gemmell, N., and Hasseldine, J. (2014) 'Taxpayers' Behavioural Responses and Measures of Tax Compliance "Gaps": A Critique and a New Measure', Fiscal Studies 35(3): 275296, doi: 10.1111/j.1475-5890.2014.12031.x

Goodfellow, T. (2015) Taxing the Urban Boom: Property Taxation and Land Leasing in Kigali and Addis Ababa, ICTD Working Paper 38, Brighton: International Centre for Tax and Development

and Owen, O. (forthcoming) Taxation, Property Rights and the Social Contract in Lagos, ICTD Working Paper, Brighton: International Centre for Tax and Development

Gupta, A. (2007) Determinants of Tax Revenue Efforts in Developing Countries, Washington DC: IMF

Hearson, M. and Kangave, J. (2014) A Review of Uganda's Tax Treaties, submission to Ministry of Finance, October 2014

IMF (2016) How to Design and Enforce Tobacco Taxes, Washington DC: IMF (2015) Current Challenges in Revenue Mobilisation: Improving Tax Compliance, Washington DC: IMF

(2014) Spillovers in International Corporate Taxation, Washington DC: IMF 
_ (2012) Mongolia: Technical Assistance Report - Safeguarding Domestic Revenue - A Mongolian DTA Model, Washington DC: IMF

— OECD, UN and World Bank (2015) Options for Low Income Countries' Effective and Efficient Use of Tax Incentives for Investment, Paris: OECD

Jerven, M. (2013) Poor Numbers: How We Are Misled by African Development Statistics and What to Do About It, Ithaca: Cornell University Press

Jibao, S. and Prichard, W. (2016) 'Rebuilding Local Government Finances After Conflict: Lessons from a Property Tax Reform Programme in Post-Conflict Sierra Leone', Journal of Development Studies 52(12): 1759-1775, doi: 10.1080/00220388.2016.1153073

and van den Boogaard, V. (2017) Informal Taxation in Post-Conflict Sierra Leone: Taxpayers' Experiences and Perceptions, ICTD Working Paper 66, Brighton: International Centre for Tax and Development

Johannesen, N. and Pirttilä, J. (2016) Capital Flight and Development, Helsinki: UNU-WIDER

Kangave, J., Nakoto, S., Waiswa, R. and Zzimbe, P. (2016) Boosting Revenue Collection through Taxing High Net Worth Individuals: The Case of Uganda, ICTD Working Paper 45, Brighton: International Centre for Tax and Development

Keen, M. (2013) The Anatomy of the VAT, Washington DC: IMF and Mansour, M. (2009) Revenue Mobilization in Sub-Saharan Africa: Challenges from Globalization, Washington DC: IMF

Kinda, T. (2014) The Quest for Non-Resource-Based FDI: Do Taxes Matter?, Washington DC: IMF

Kloeden, D. (2011) Revenue Administration Reforms in Anglophone Africa Since the Early 1990s, Washington DC: IMF

Laporte, B. and de Quatrebarbes, C. (2015) 'What do we know about the sharing of mineral resource rent in Africa?', Resources Policy 46, Part 2: 239-249, doi: <https://doi.org/10.1016/j.resourpol.2015.10.005>

Lundstøl, O., Raballand, G. and Nyirongo, F. (2013) Low Government Revenue from the Mining Sector in Zambia and Tanzania: Fiscal Design, Technical Capacity or Political Will?, Working Paper 9, Brighton: International Centre for Tax and Development

McCluskey, R. (2016) 'Why African Governments Should Tax the Rich', The Conversation, April 3, <https://theconversation.com/african-governments-arent-taxing-the-rich-whythey-should-57162>

Minh Le, T., Moreno-Dodson, B. and Bayraktar, N. (2012) Tax Capacity and Tax Effort. Extended Cross-Country Analysis from 1994, Policy Research Working Paper 6252, Washington DC: World Bank 
Moore, M. (2015) 'Tax and the Governance Dividend', in A.M. Kjaer, L. Buur and L. EngbergPedersen (eds), Perspectives on Politics, Production and Public Administration in Africa, Copenhagen: Danish Institute of International Studies

and Lundstol, O. (2016) What Have We Learned about Mining Taxation in Africa?, ICTD Summary Brief 1, Brighton: International Centre for Tax and Development

National Cancer Institute (2017) The Economics of Tobacco and Tobacco Control (Executive Summary), National Cancer Institute

OECD (2017) Revenue Statistics in Africa 1990-2015, Paris: OECD

(2013) Analysis of Tax Expenditures in Ghana, Paris: OECD Tax and Development Program

Paler, L., Prichard, W., Sanchez de la Sierra, R. and Samii, C. (2017) Survey on Total Tax Burden in the DRC, Final Report, Kinshasa: Department for International Development

Pessino, C. and Fenochietto, R. (2010) 'Determining Countries' Tax Effort', Hacienda Public Espanola/Revista de Economia Publica 194(4): 65-87

Piancastelli, M. (2001) Measuring the Tax Effort of Developed and Developing Countries. Cross-Country Panel Data Analysis -1985/95, Rio de Janeiro: Instituto de Pesquisa Economica Aplicada

Readhead, A. (2017) Toolkit for Transfer Pricing Risk Assessment in the African Mining Industry, Eschborn and Bonn: GIZ

- (2016) Preventing Tax Base Erosion in Africa: a Regional Study of Transfer Pricing Challenges in the Mining Sector, London: Natural Resources Governance Institute

Savedoff, W., and Alwang, A. (2015) The Single Best Health Policy In the World: Tobacco Taxes, Washington DC: Center for Global Development

Strauss, J. (2008) 'Rethinking Institutional Capacity and Tax Regimes: The Case of the SinoForeign Salt Inspectorate in Republican China', in D. Brautigam, O-H. Fjeldstad and M. Moore (eds), Taxation and State-Building in Developing Countries: Capacity and Consent, Cambridge: Cambridge University Press

Therkildsen, O. (2012) Democratisation in Tanzania. No Taxation without Exemptions, American Political Science Association, New Orleans

Van Walbeek, C., Blecher, E., Gilmore, A. and Ross, H. (2013) 'Price and Tax Measures and Illicit Trade in the Framework Convention on Tobacco Control: What We Know and What Research Is Required', Nicotine \& Tobacco Research 15(4): 767-776. doi: $10.1093 /$ ntr/nts 170

Vines, A., Wong, L., Weimer, M. and Campos, I. (2009) Thirst for African Oil: Asian National Oil Companies in Nigeria and Angola. A Chatham House Report, London: Royal Institute of International Affairs

Waris, A. (2017) How Kenya has Implemented and Adjusted to the Changes in International Transfer Pricing Regulations: 1920-2016, ICTD Working Paper 69, Brighton: International Centre for Tax and Development 
World Bank (2017) Tobacco Tax Reform: At the Crossroads of Health and Development. A Multisectoral Perspective, Washington DC: World Bank

Zake, J. (2011) Customs Administration Reform and Modernization in Anglophone Africa Early 1990s to Mid-2010, Washington DC: IMF

Zucman, G. (2015) The Hidden Wealth of Nations. The Scourge of Tax Havens, Chicago and London: University of Chicago Press 


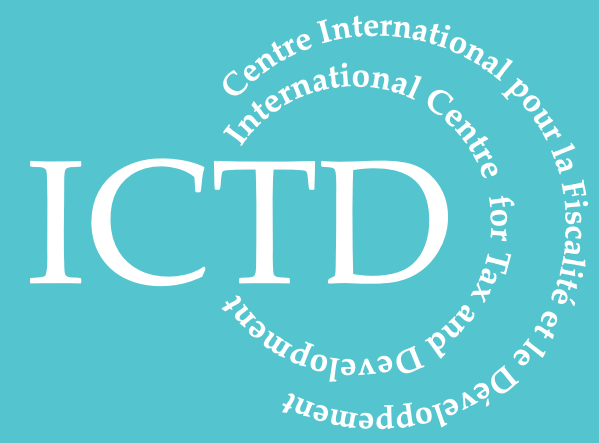

International Centre for Tax and Development at the Institute of Development Studies

Brighton BN1 9RE, UK

T: +44 (0) 1273606261

F: $+44(0) 1273621202$

E: info@ictd.ac

www.ictd.ac 